\title{
ANALISIS PEMENUHAN KEBUTUHAN RUANG TERBUKA HIJAU PUBLIK KOTA PROBOLINGGO
}

\author{
Khabib Royani ${ }^{1}$ \\ Linda Dwi Rohmadiani² \\ Program Studi Perencanaan Wilayah dan Kota Universitas PGRI Adi Buana Surabaya ${ }^{1,2}$ \\ ${ }^{1}$ Penulis Korespondensi e-mail: linda@unipasby.ac.id
}

\section{ABSTRACT}

Public Green Open Space (RTH) is a space that has an ecological function in the process of building a city. Law No. 26 of 2007 mandates that the proportion of public green open space (RTH) of a city is at least $20 \%$ of the city's area. The purpose of this study was to analyze the broad need for Public RTH and directions for meeting the needs of Public RTH based on location. The research method used was mixed methods with evaluative analysis techniques and intersect overlay with GIS. Methods of data collection by means of agency surveys, documentation and observation. The results showed that the need for additional public green open space based on an area of 840.53 ha, based on a population of 210.12 ha, based on oxygen demand of 535.79 ha and based on water needs of $486.18 \mathrm{ha}$. Directions for fulfilling the needs of public green open space for the City of Probolinggo by utilizing city government assets covering an area of $223.80 \mathrm{ha}$, and the drawback is by purchasing community land. Land assets are the main priority for meeting the needs of public green open space in the city of Probolinggo.

Keywords: Land Asset, Need for Green Open Space, Public Green Open Space

\begin{abstract}
ABSTRAK
Ruang Terbuka Hijau (RTH) Publik merupakan ruang yang memiliki fungsi ekologis dalam proses pembangunan sebuah kota. Undang-undang No. 26 Tahun 2007 mengamanatlan bahwa proporsi Ruang Terbuka Hijau (RTH) Publik suatu kota paling sedikit 20\% dari luas wilayah kota. Tujuan penelitian ini adalah menganalisis kebutuhan luas RTH Publik dan arahan pemenuhan kebutuhan RTH Publik berdasarkan lokasi. Metode penelitian yang digunakan metode campuran dengan teknik analisis evaluatif dan overlay intersect dengan GIS. Metode pengumpulan data dengan cara survey instansi, dokumentasi dan observasi. Hasil penelitian menunjukkan bahwa kebutuhan penambahan RTH Publik berdasarkan luas wilayah seluas 840,53 ha, berdasarkan jumlah penduduk seluas 210,12 ha, berdasarkan kebutuhan oksigen seluas 535,79 ha dan berdasarkan kebutuhan air seluas 486,18 ha. Arahan pemenuhan kebutuhan RTH Publik Kota Probolinggo dengan cara pemanfaatan tanah aset pemerintah kota seluas 223,80 ha, dan kekurangannya dengan melakukan pembelian tanah masyarakat Tanah aset merupakan prioritas utama untuk pemenuhan kebutuhan RTH Publik di Kota Probolinggo.

Kata Kunci: Kebutuhan Luas RTH, Ruang Terbuka Hijau Pubik, Tanah Aset
\end{abstract}


Jurnal Planologi Vol. 18 No. 2, Oktober 2021 Available : http://jurnal.unissula.ac.id/index.php/psa

\section{PENDAHULUAN}

Kota Probolinggo merupakan salah satu kota yang terletak di Bagian Utara Propinsi Jawa Timur dan berbatasan langsung dengan Selat Madura. Luas Kota Probolinggo kurang lebih 5.504 ha. Berdasarkan Peraturan Daerah Kota Probolinggo Nomor 20 Tahun 2006 tentang Penataan dan Pengembangan Kelembagaan Kecamatan, Kota Probolinggo terdiri dari 5 (lima) kecamatan yang membawahi 29 Kelurahan. Jumlah penduduk di Kota Probolinggo pada Tahun 2018 sebesar 235.211 jiwa, dengan kepadatan penduduk sebesar 43 jiwa/ha. Ditinjau dari Peraturan Daerah Provinsi Jawa Timur No. 5 tahun 2012 tentang Rencana Tata Ruang Wilayah Provinsi Jawa Timur Tahun 2011-2031, Kota Probolinggo ditetapkan sebagai Pusat Kegiatan Wilayah bagi Kabupaten Probolinggo dan Kabupaten Lumajang, maka Kota Probolinggo perlu menyediakan sarana dan prasarana yang memadai salah satunya berupa Ruang Terbuka Hijau (RTH) Publik.

Ketersediaan Ruang Terbuka Hijau (RTH) Publik di Kota Probolinggo berdasarkan data Dinas Pekerjaan Umum dan Penataan Ruang Kota Probolinggo Tahun 2019 mencapai luas kurang lebih 166 ha atau baru mencapai 3\% dari total luas wilayah. Ruang Terbuka Hijau (RTH) Publik Kota Probolinggo pada Tahun 2020 sesuai dengan Peraturan Menteri Pekerjaan Umum Nomor 05/PRT/M/2008 tentang Pedoman Penyediaan dan Pemanfaatan Ruang Terbuka Hijau di Kawasan Perkotaan berupa taman dan hutan kota, jalur hijau jalan,dan fungsi tertentu (sempadan sungai, sempadan pantai, kawasan mata air, sempadan rel kereta api dan pemakaman). RTH taman dan hutan kota Kota Probolinggo Tahun 2020 seluas 24,33 ha (0,44\%) meliputi taman kota seluas 9,20 ha tersebar di seluruh kecamatan, taman rekreasi seluas 5,86 ha berada di Kecamatan Mayangan dan hutan kota seluas 9,27 ha tersebar di seluruh kecamatan. RTH jalur hijau jalan Tahun 2020 seluas 12,45 ha (0,23\%) tersebar di seluruh kecamatan. RTH fungsi tertentu Tahun 2020 seluas 223,52 ha (4,06\%) meliputi sempadan rel kereta api di seluruh kecamatan seluas 25,30 ha, sempadan pantai di Kecamatan Mayangan dan Kecamatan Kademangan seluas 85,03 ha, sempadan sungai di seluruh kecamatan seluas 61,45 ha, kawasan sekitar mata air seluas 7,36 ha di Kecamatan Wonoasih, Kecamatan Mayangan, Kecamatan Kanigaran dan Kecamatan Kedopok serta pemakaman tersebar di seluruh kecamatan seluas 44,38 ha.

Undang-Undang No. 26 Tahun 2007 tentang Penataan Ruang Pasal 29 Ayat 3 disebutkan bahwa proporsi ruang terbuka hijau publik pada wilayah kota paling sedikit $20 \%$ dari luas wilayah kota. Berpedoman pada pasal tersebut, maka proporsi ruang 
terbuka hijau publik minimal Kota Probolinggo seluas kurang lebih 1.100 ha, sehingga sampai dengan Tahun 2020 masih diperlukan penambahan ruang terbuka hijau publik seluas kurang lebih 935 ha atau $17 \%$.

Tujuan dilakukan penelitian ini adalah untuk menganalisis kebutuhan luas RTH Publik berdasarkan luas wilayah dan arahan lokasi pemenuhan kebutuhan RTH Publik di Kota Probolinggo. Harapannya penelitian ini dapat dijadikan sebagai bahan evaluasi dan masukan untuk peningkatan kualitas dan prosentase dari penyediaan RTH Publik di Kota Probolinggo serta sebagai bahan pertimbangan dalam penyusunan Rencana Detail Tata Ruang Kota di Kota Probolinggo.

\section{METODOLOGI}

Metode penelitian yang digunakan adalah deskriptif dengan pendekatan kuantitatif dan kualitatif. Metode pengumpulan data dengan melakukan observasi, dokumentasi, dan survei instansi (Bappeda, Dinas PUPR, DLHK, Dinas Pertanian, Bagian Aset, BPS, Kecamatan dan Kelurahan) di Kota Probolinggo.

Analisis kebutuhan luas RTH Publik menggunakan metode analisis kuantitatif dengan teknik penyediaan RTH Publik berdasarkan luas wilayah sesuai dengan Pedoman Penyediaan dan Pemanfaatan Ruang Terbuka Hijau di Kawasan Perkotaan. Arahan lokasi pemenuhan RTH Publik menggunakan analisis kualitatif dengan teknik triangulasi dan overlay (Intersect Themes) dengan Sistem Informasi Geografis (GIS) seperti pada Gambar 1.

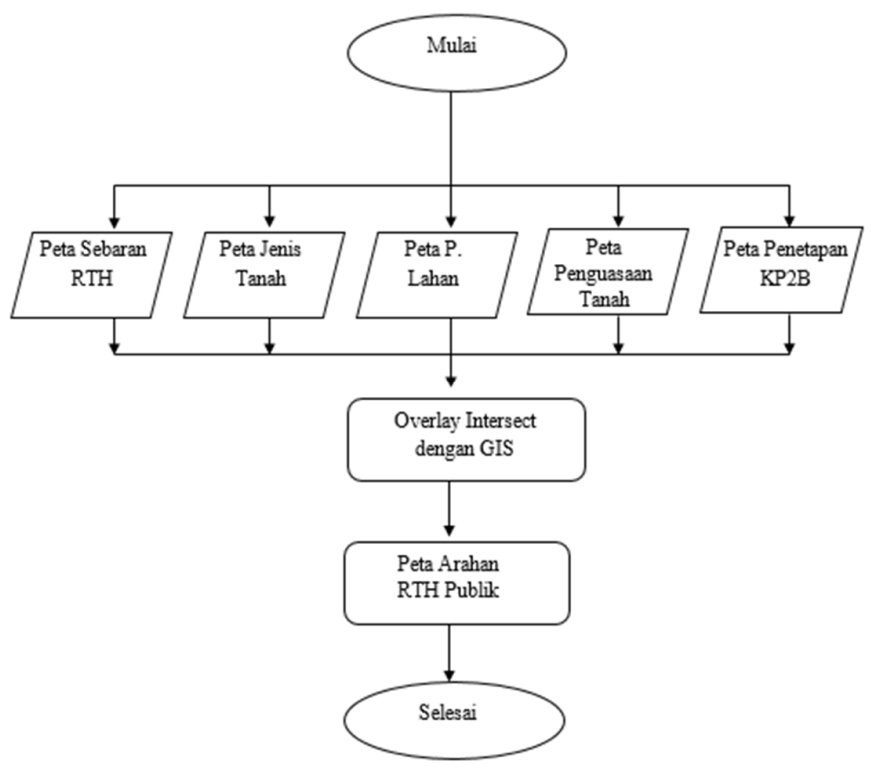

Gambar 1. Flowchart Analisis Overlay Intersect 


\section{HASIL DAN PEMBAHASAN}

\section{Distribusi Keruangan Ruang Terbuka Hijau (RTH) Publik di Kota Probolinggo}

Ruang terbuka hijau publik yang dimaksud dalam penelitian ini adalah ruang luar yang dapat diakses oleh masyarakat umum (Ningtyas, 2019). Ruang Terbuka Hijau (RTH) Publik Kota Probolinggo berdasarkan hasil dokumentasi dan observasi mencapai luas 260,30 Ha atau 4,73\% dari luas wilayah Kota Probolinggo (Tabel 1) sedangkan data RTH Publik dari Dinas Pekerjaan Umum dan Penataan Ruang seluas 166,21 ha atau baru mencapai 3,02\% dari luas wilayah Kota Probolinggo. Kondisi geografisnya yang berbatasan langsung Selat Madura, RTH Publik di Kota Probolinggo berorientasi pada kota tepian pantai atau kota pesisir. Fungsi RTH pada kota pantai berfungsi sebagai greenbelt dari kenaikan permukaan air laut, tsunami, intrusi air laut, dan abrasi pantai (Priananta, 2010). Pola distribusi RTH Publik di Kota Probolinggo merupakan gabungan antara RTH struktural dan RTH non struktural yang menyeimbangkan pola hierarki planologis yang bersifat antroposentris dengan ekosentris. Pola ekologis disini dapat mengelompok, memanjang atau tersebar sedangkan pola planologis mengikuti struktur ruang perkotaan (Islami \& Suheri, 2016) (Karouw et. al, 2019). 
Tabel 1. Jenis, Sebaran dan Luasan Ruang Terbuka Hijau (RTH) Publik

Kota Probolinggo Tahun 2020

\begin{tabular}{|c|c|c|c|c|c|c|c|c|c|c|c|c|c|}
\hline \multirow[b]{3}{*}{ No } & \multirow[b]{3}{*}{ Kecamatan } & \multicolumn{10}{|c|}{ Ruang Terbuka Hijau Publik (ha) } & \multirow[b]{3}{*}{$\begin{array}{c}\text { Lua } \\
\text { s } \\
\text { Kec } \\
\dot{\text { (ha) }}\end{array}$} & \multirow[b]{3}{*}{$\%$} \\
\hline & & \multicolumn{3}{|c|}{$\begin{array}{l}\text { RTH Taman } \\
\text { dan Hutan } \\
\text { Kota }\end{array}$} & $\begin{array}{c}\text { RT } \\
\text { H } \\
\text { JH }\end{array}$ & \multicolumn{5}{|c|}{ RTH Fungsi Tertentu } & \multirow[b]{2}{*}{$\begin{array}{l}\text { To } \\
\text { tal }\end{array}$} & & \\
\hline & & $\begin{array}{c}\text { Ta } \\
\text { ma } \\
\text { n } \\
\text { Ko } \\
\text { ta }\end{array}$ & $\begin{array}{c}\text { Ta } \\
\text { ma } \\
\mathbf{n} \\
\mathbf{R e} \\
\mathbf{k} \\
\text { rea } \\
\text { si }\end{array}$ & $\begin{array}{c}\text { Hu } \\
\text { ta } \\
\text { n } \\
\text { Ko } \\
\text { ta }\end{array}$ & $\begin{array}{c}\text { Hal } \\
\text { an } \\
\text { dan } \\
\text { Me } \\
\text { dia } \\
\text { n } \\
\text { Jal } \\
\text { an }\end{array}$ & $\begin{array}{c}\text { pada } \\
\text { n } \\
\text { Pant } \\
\text { ai } \\
\text { (Hut } \\
\text { an } \\
\text { Man } \\
\text { g } \\
\text { rove) }\end{array}$ & $\begin{array}{c}\text { Sem } \\
\text { pada } \\
\text { n } \\
\text { Sung } \\
\text { ai }\end{array}$ & $\begin{array}{c}\text { Ka } \\
\text { was } \\
\text { an } \\
\text { Seki } \\
\text { tar } \\
\text { Mat } \\
\text { a } \\
\text { Air }\end{array}$ & $\begin{array}{c}\text { Sem } \\
\text { pada } \\
\text { n Rel } \\
\text { Kere } \\
\text { ta } \\
\text { Api }\end{array}$ & $\begin{array}{c}\text { Ma } \\
\text { ka } \\
\text { m }\end{array}$ & & & \\
\hline 1 & Kademangan & $\begin{array}{c}0,6 \\
1\end{array}$ & $\begin{array}{c}0,0 \\
0\end{array}$ & $\begin{array}{c}1,5 \\
7\end{array}$ & $\begin{array}{c}2,7 \\
5\end{array}$ & 50,49 & 11,20 & 0,00 & 5,23 & $\begin{array}{c}9,7 \\
8\end{array}$ & $\begin{array}{l}81 \\
63\end{array}$ & $\begin{array}{l}1.40 \\
1,00\end{array}$ & $\begin{array}{l}5, \\
8 \\
3\end{array}$ \\
\hline 2 & Wonoasih & $\begin{array}{c}0,3 \\
6\end{array}$ & $\begin{array}{c}0,0 \\
0\end{array}$ & $\begin{array}{c}0,8 \\
1\end{array}$ & $\begin{array}{c}2,4 \\
0\end{array}$ & 0,00 & 19,49 & 1,30 & 3,64 & $\begin{array}{l}15, \\
52\end{array}$ & $\begin{array}{c}43 \\
52\end{array}$ & $\begin{array}{l}1.07 \\
9,24\end{array}$ & $\begin{array}{l}4, \\
0 \\
3\end{array}$ \\
\hline 3 & Mayangan & $\begin{array}{c}3,9 \\
1\end{array}$ & $\begin{array}{c}5,8 \\
6\end{array}$ & $\begin{array}{c}1,6 \\
0\end{array}$ & $\begin{array}{c}1,9 \\
8\end{array}$ & 34,54 & 10,22 & 0,07 & 9,65 & $\begin{array}{c}9,2 \\
7\end{array}$ & $\begin{array}{l}77 \\
09\end{array}$ & $\begin{array}{c}978, \\
11\end{array}$ & $\begin{array}{l}7, \\
8 \\
8\end{array}$ \\
\hline 4 & Kanigaran & $\begin{array}{c}1,7 \\
4\end{array}$ & $\begin{array}{c}0,0 \\
0\end{array}$ & $\begin{array}{c}2,5 \\
9\end{array}$ & $\begin{array}{c}2,3 \\
8\end{array}$ & 0,00 & 10,96 & 0,34 & 4,61 & $\begin{array}{c}6,9 \\
7\end{array}$ & $\begin{array}{c}29 \\
59\end{array}$ & $\begin{array}{c}865 \\
20\end{array}$ & $\begin{array}{l}3, \\
4 \\
2\end{array}$ \\
\hline 5 & Kedopok & $\begin{array}{c}2,5 \\
8\end{array}$ & $\begin{array}{c}0,0 \\
0\end{array}$ & $\begin{array}{c}2,7 \\
2\end{array}$ & $\begin{array}{c}2,9 \\
4\end{array}$ & 0,00 & 9,58 & 5,65 & 2,17 & $\begin{array}{c}2,8 \\
4\end{array}$ & $\begin{array}{l}28 \\
48\end{array}$ & $\begin{array}{l}1.18 \\
0,59\end{array}$ & $\begin{array}{l}2, \\
4 \\
1\end{array}$ \\
\hline & I Keseluruhan & $\begin{array}{c}9,2 \\
0\end{array}$ & $\begin{array}{c}5,8 \\
6\end{array}$ & $\begin{array}{c}9,2 \\
7\end{array}$ & $\begin{array}{l}12, \\
45\end{array}$ & 85,03 & 61,45 & 7,36 & 25,30 & $\begin{array}{l}44, \\
38\end{array}$ & $\begin{array}{c}26 \\
0,3 \\
0 \\
\end{array}$ & $\begin{array}{l}5.50 \\
4,14\end{array}$ & $\begin{array}{l}4, \\
7 \\
3 \\
\end{array}$ \\
\hline $\begin{array}{r}\text { Prose } \\
\text { Lua }\end{array}$ & $\begin{array}{l}\text { sse }(\%) \text { Terhadap } \\
\text { Kota Probolingo }\end{array}$ & $\begin{array}{c}0,1 \\
7\end{array}$ & $\begin{array}{c}0,1 \\
1\end{array}$ & $\begin{array}{c}0,1 \\
7\end{array}$ & $\begin{array}{c}\mathbf{0 , 2} \\
3\end{array}$ & 1,54 & 1,12 & $\mathbf{0 , 1 3}$ & 0,46 & $\begin{array}{c}0,8 \\
1\end{array}$ & $\begin{array}{c}4,7 \\
3\end{array}$ & & \\
\hline
\end{tabular}

Sumber: Hasil Obervasi, Dokumentasi dan Digitasi Peneliti Tahun 2020

\section{Kebutuhan Ruang Terbuka Hijau (RTH) Publik di Kota Probolinggo}

Kebutuhan RTH Publik berdasarkan luas wilayah di Kota Probolinggo seluas 1.100,83 ha, ketersedian RTH Publik di Kota Probolinggo saat ini seluas 260,30 ha, sehingga diperlukan penambahan RTH Publik seluas 840,53 ha atau 76,35\% dari luas yang dibutuhkan. Penambahan RTH Publik untuk masing-masing kecamatan, yaitu: (Gambar 2). 


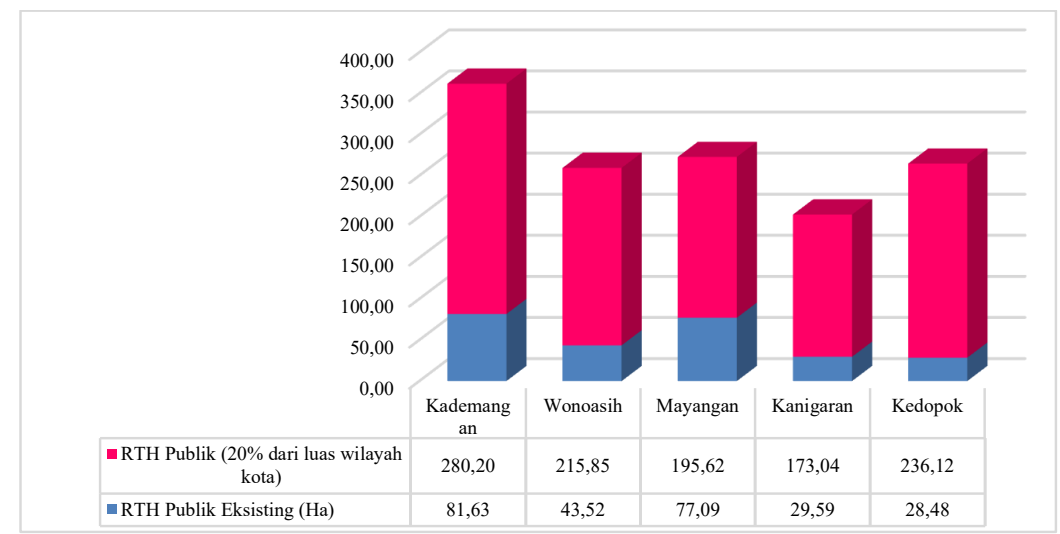

Gambar 2. Kebutuhan RTH Publik Kota Probolinggo Berdasarkan Luas Wilayah Tahun 2020

\section{Arahan Pemenuhan Kebutuhan Ruang Terbuka Hijau (RTH) Publik Di Kota Probolinggo Berdasarkan Lokasi}

Hasil dari analisis triangulasi merekomendasikan perlunya penambahan RTH Publik di Kota Probolinggo (Tabel 2). Kondisi ini sejalan dengan hasil penelitian pada Tahun 2013 yang menyatakan berdasarkan analisis kebutuhan dari aspek kebutuhan oksigen, Kota Probolinggo masih membutuhkan penambahan luasan ruang terbuka hijau publik (Setiawan \& Hermana, 2013).

Tabel 2. Analisis Triangulasi Data dan Analisis RTH Publik di Kota Probolinggo Tahun 2020

\begin{tabular}{|c|c|c|c|c|c|c|}
\hline $\begin{array}{l}\mathbf{N} \\
\mathbf{0}\end{array}$ & $\begin{array}{c}\text { Jenis } \\
\text { Infrastruk } \\
\text { tur }\end{array}$ & $\begin{array}{c}\text { Standar } \\
\text { Yang } \\
\text { Digunakan }\end{array}$ & $\begin{array}{c}\text { Data Instansi } \\
\text { Terkait }\end{array}$ & Data dan Analisis & $\begin{array}{c}\text { Memenuhi/ } \\
\text { Tidak } \\
\text { Memenuhi } \\
\text { Standar } \\
\end{array}$ & Rekomendasi \\
\hline 1 & $\begin{array}{l}\text { RTH } \\
\text { Publik }\end{array}$ & $\begin{array}{l}\text { Permen PU } \\
\text { No. } \\
\text { 5/PRT/M/ } \\
\text { 2008 } \\
\text { Penyediaan } \\
\text { RTH } \\
\text { berdasarkan } \\
\text { luas wilayah } \\
\text { di perkotaan } \\
\text { adalah } \\
\text { sebagai } \\
\text { berikut: } \\
\text { a. ruang } \\
\text { terbuka } \\
\text { hijau di } \\
\text { perkotaan } \\
\text { terdiri dari } \\
\text { RTH Publik } \\
\text { dan RTH } \\
\text { privat; } \\
\text { b. proporsi } \\
\text { RTH pada } \\
\text { wilayah } \\
\text { perkotaan } \\
\text { adalah } \\
\text { sebesar } \\
\text { minimal } \\
\text { 30\% } \\
\text { meliputi } \\
\text { 20\% ruang }\end{array}$ & $\begin{array}{l}\text { a. Dinas } \\
\text { Lingkung } \\
\text { an Hidup } \\
\text { Kota } \\
\text { Proboling } \\
\text { go luas } \\
\text { RTH } \\
\text { Publik } \\
\text { Tahun } \\
2020: \\
214,48 \\
\text { ha, } \\
\text { dengan } \\
\text { perincian: } \\
\text { - Taman } \\
\text { Kota: } \\
9,03 \text { ha } \\
\text { - Taman } \\
\text { Rekreas } \\
\text { i: } 5,46 \\
\text { ha } \\
\text { - Hutan } \\
\text { Kota: } \\
9,14 \text { ha } \\
\text { - Makam } \\
: 43,78 \\
\text { ha } \\
\text { - RTH } \\
\text { Jalan: }\end{array}$ & $\begin{array}{l}\text { a. Luas RTH Publik } \\
\text { Tahun 2020: } 260,30 \\
\text { ha, dengan perincian; } \\
\text { - Taman Kota : 9,20 ha } \\
\text { - Taman Rekreasi : }\end{array}$ & $\begin{array}{l}\text { a. Data } \\
\text { Instansi } \\
\text { Terkait: } \\
\text { Dinas } \\
\text { Pekerjaa } \\
\text { n Umum } \\
\text { dan } \\
\text { Penataan } \\
\text { Ruang: } \\
\text { Belum } \\
\text { memenu } \\
\text { hi } \\
\text { standar } \\
\text { karena } \\
\text { RTH } \\
\text { Publik } \\
\text { eksisting } \\
\text { baru } \\
\text { mencapa } \\
\text { i luas } \\
\text { 166,21 } \\
\text { ha } \\
\text { (3,02\%) } \\
\text { dari luas } \\
\text { wilayah } \\
\text { b. Data } \\
\text { dan } \\
\text { Analisis } \\
\text { Belum } \\
\text { memenu }\end{array}$ & $\begin{array}{ll}\text { a. } & \text { Perlu } \\
\text { penambah } \\
\text { an RTH } \\
\text { Publik di } \\
\text { Kota } \\
\text { Probolingg } \\
\text { o } \\
\text { b. Penambah } \\
\text { an RTH } \\
\text { Publik } \\
\text { diprioritas } \\
\text { kan } \\
\text { memanfaat } \\
\text { kan pada } \\
\text { tanah aset } \\
\text { milik } \\
\text { Pemerinta } \\
\text { h Kota } \\
\text { Probolingg } \\
\text { o (apabila } \\
\text { ada) dan } \\
\text { tanah } \\
\text { milik } \\
\text { masyaraka } \\
\text { t. }\end{array}$ \\
\hline
\end{tabular}


Jurnal Planologi Vol. 18 No. 2, Oktober 2021 Available : http://jurnal.unissula.ac.id/index.php/psa

\begin{tabular}{|c|c|c|c|c|c|c|}
\hline $\begin{array}{l}\mathbf{N} \\
\mathbf{0}\end{array}$ & $\begin{array}{c}\text { Jenis } \\
\text { Infrastruk } \\
\text { tur }\end{array}$ & $\begin{array}{c}\text { Standar } \\
\text { Yang } \\
\text { Digunakan }\end{array}$ & $\begin{array}{c}\text { Data Instansi } \\
\text { Terkait }\end{array}$ & Data dan Analisis & $\begin{array}{c}\text { Memenuhi/ } \\
\text { Tidak } \\
\text { Memenuhi } \\
\text { Standar } \\
\end{array}$ & Rekomendasi \\
\hline & & $\begin{array}{l}\text { terbuka } \\
\text { hijau publik } \\
\text { dan } 10 \% \\
\text { terdiri dari } \\
\text { ruang } \\
\text { terbuka } \\
\text { hijau privat; } \\
\text { c. apabila luas } \\
\text { RTH baik } \\
\text { publik } \\
\text { maupun } \\
\text { privat di } \\
\text { kota yang } \\
\text { bersangkuta } \\
\text { n telah } \\
\text { memiliki } \\
\text { total luas } \\
\text { lebih besar } \\
\text { dari } \\
\text { peraturan } \\
\text { atau } \\
\text { perundanga } \\
\text { n yang } \\
\text { berlaku, } \\
\text { maka } \\
\text { proporsi } \\
\text { tersebut } \\
\text { harus tetap } \\
\text { dipertahank } \\
\text { an } \\
\text { keberadaan } \\
\text { nya. }\end{array}$ & $\begin{array}{l}\text { 12,34 } \\
\text { ha } \\
\text { - Hutan } \\
\text { Mangro } \\
\text { ve } \\
\text { (sempa } \\
\text { dan } \\
\text { pantai): } \\
\text { 134,73 } \\
\text { ha } \\
\text { b. Dinas } \\
\text { Pekerjaan } \\
\text { Umum } \\
\text { dan } \\
\text { Penataan } \\
\text { Ruang } \\
\text { Kota } \\
\text { Proboling } \\
\text { go luas } \\
\text { RTH } \\
\text { Publik } \\
\text { Tahun } \\
\text { 2020: } \\
\text { 166,21 } \\
\text { ha, } \\
\text { dengan } \\
\text { perincian: } \\
\text { - Taman } \\
\text { Kota: } \\
9,20 \text { ha } \\
\text { - Taman } \\
\text { Rekreas } \\
\text { i: } 5,86 \\
\text { ha } \\
\text { - Hutan } \\
\text { Kota: } \\
9,27 \text { ha } \\
\text { - RTH } \\
\text { Jalan: } \\
12,45 \\
\text { ha } \\
\text { - Hutan } \\
\text { Mangro } \\
\text { ve } \\
\text { (Sempa } \\
\text { dan } \\
\text { Pantai): } \\
85,03 \\
\text { ha } \\
\text { - Makam } \\
\text { : 44,38 } \\
\text { ha }\end{array}$ & 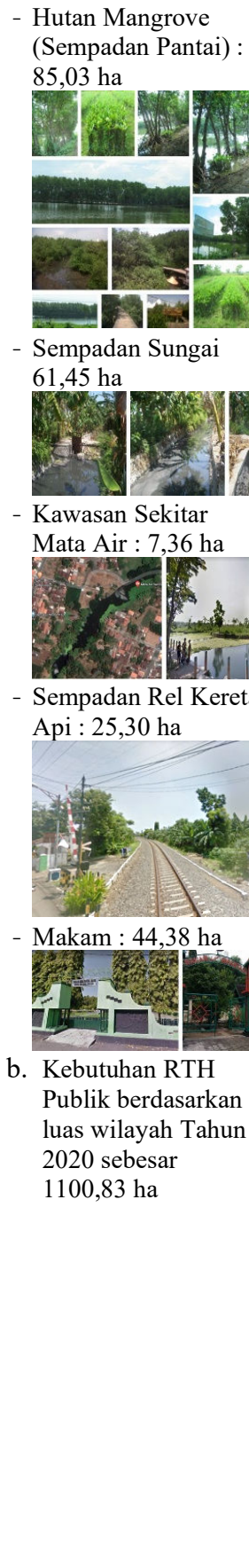 & $\begin{array}{l}\text { hi } \\
\text { standar } \\
\text { karena } \\
\text { ketersedi } \\
\text { an RTH } \\
\text { Publik di } \\
\text { Kota } \\
\text { Probolin } \\
\text { ggo baru } \\
\text { mencapa } \\
\text { i luas } \\
260,30 \\
\text { ha } \\
(4,73 \%) \\
\text { dari luas } \\
\text { wilayah }\end{array}$ & \\
\hline
\end{tabular}

Sumber : Hasil Analisa Tahun 2020

Rekomendasi analisis triangulasi menyebutkan bahwa penambahan RTH Publik diprioritaskan pada tanah aset Pemerintah Kota Probolinggo dan tanah milik masyarakat. Kesesuaian alternatif lokasi RTH publik berdasarkan penggunaan lahan, kepadatan penduduk, kelerengan dan aksesbilitas (Utami \& Susanti, 2019). Analisis ini didasarkan 
pada hasil analisis kebutuhan RTH Publik yang sudah dilakukan dan hasil overlay antara peta penggunaan lahan eksisting, peta jenis tanah, peta penetapan Kawasan Pertanian Pangan Berkelanjutan (KP2B), dan peta penguasaan tanah atau ijin lokasi di Kota Probolinggo maka diperoleh dengan rumus:

\section{Potensi Pengembangan RTH = Lahan Tidak Terbangun-KP2B-Lahan Berizin}

Hasil dari perhitungan rumus diatas adalah potensi pengembangan RTH Publik Kota Probolinggo Tahun 2020 seluas 2.084,73 ha dengan penyebaran sebagai berikut: (Tabel 2)

Tabel 3. Lahan Potensi Pengembangan RTH Publik Kota Probolinggo Tahun 2020

\begin{tabular}{|c|c|c|c|c|c|c|}
\hline No & Kecamatan & $\begin{array}{c}\text { Luas } \\
\text { Wilayah } \\
\text { (Ha) }\end{array}$ & $\begin{array}{c}\text { Lahan } \\
\text { Tidak } \\
\text { Terbangun } \\
\text { (Ha) }\end{array}$ & $\begin{array}{c}\text { Lahan } \\
\text { Yang } \\
\text { Ditetapkan } \\
\text { Menjadi } \\
\text { KP2B (Ha) } \\
\end{array}$ & $\begin{array}{c}\text { Lahan Tidak } \\
\text { Terbangun } \\
\text { Yang Sudah } \\
\text { Memiliki Izin } \\
\text { (Ha) } \\
\end{array}$ & $\begin{array}{c}\text { Lahan Yang } \\
\text { Berpotensi } \\
\text { Untuk } \\
\text { Pengembangan } \\
\text { RTH (Ha) } \\
\end{array}$ \\
\hline 1 & Kademangan & $1.401,00$ & 958,91 & 275,76 & 23,93 & 659,21 \\
\hline 2 & Wonoasih & $1.079,24$ & 774,44 & 417,62 & 2,48 & 354,34 \\
\hline 3 & Mayangan & 978,11 & 283,90 & 11,44 & 20,39 & 252,07 \\
\hline 4 & Kanigaran & 865,20 & 362,64 & 122,48 & 18,40 & 221,76 \\
\hline 5 & Kedopok & $1.180,59$ & 896,00 & 272,12 & 26,53 & 597,34 \\
\hline & Total & $5.504,14$ & $3.275,89$ & $1.099,42$ & 91,74 & $2.084,73$ \\
\hline
\end{tabular}

Sumber : Hasil Analisa Tahun 2020

Lahan potensi pengembangan RTH Publik seluas 2.084,73 ha tersebut terdiri dari tanah aset Pemerintah Kota Probolinggo seluas 223,80 ha dan tanah milik masyarakat seluas 1.860,93 ha dijabarkan pada Tabel berikut dan Gambar 3.

Tabel 4. Lahan Potensi Pengembangan RTH Publik Kota Probolinggo Berdasarkan Kepemilikan Lahan Tahun 2020

\begin{tabular}{|l|l|r|r|r|}
\hline No & Kecamatan & $\begin{array}{c}\text { Lahan Yang Dapat } \\
\text { Dimanfaatkan Menjadi } \\
\text { RTH Publik (Ha) }\end{array}$ & $\begin{array}{c}\text { Tanah Aset } \\
\text { Pemkot } \\
\text { (Ha) }\end{array}$ & $\begin{array}{c}\text { Tanah Milik } \\
\text { Masyarakat } \\
\text { (Ha) }\end{array}$ \\
\hline 1 & Kademangan & 659,21 & 61,98 & 597,23 \\
\hline 2 & Wonoasih & 354,34 & 28,26 & 326,08 \\
\hline 3 & Mayangan & 252,07 & 71,11 & 180,96 \\
\hline 4 & Kanigaran & 221,76 & 32,97 & 188,79 \\
\hline 5 & Kedopok & 597,34 & 29,48 & 567,86 \\
\hline & Total & $\mathbf{2 . 0 8 4 , 7 3}$ & $\mathbf{2 2 3 , 8 0}$ & $\mathbf{1 . 8 6 0 , 9 3}$ \\
\hline
\end{tabular}

Sumber : Bappedalitbang dan Hasil Analisa Tahun 2020 


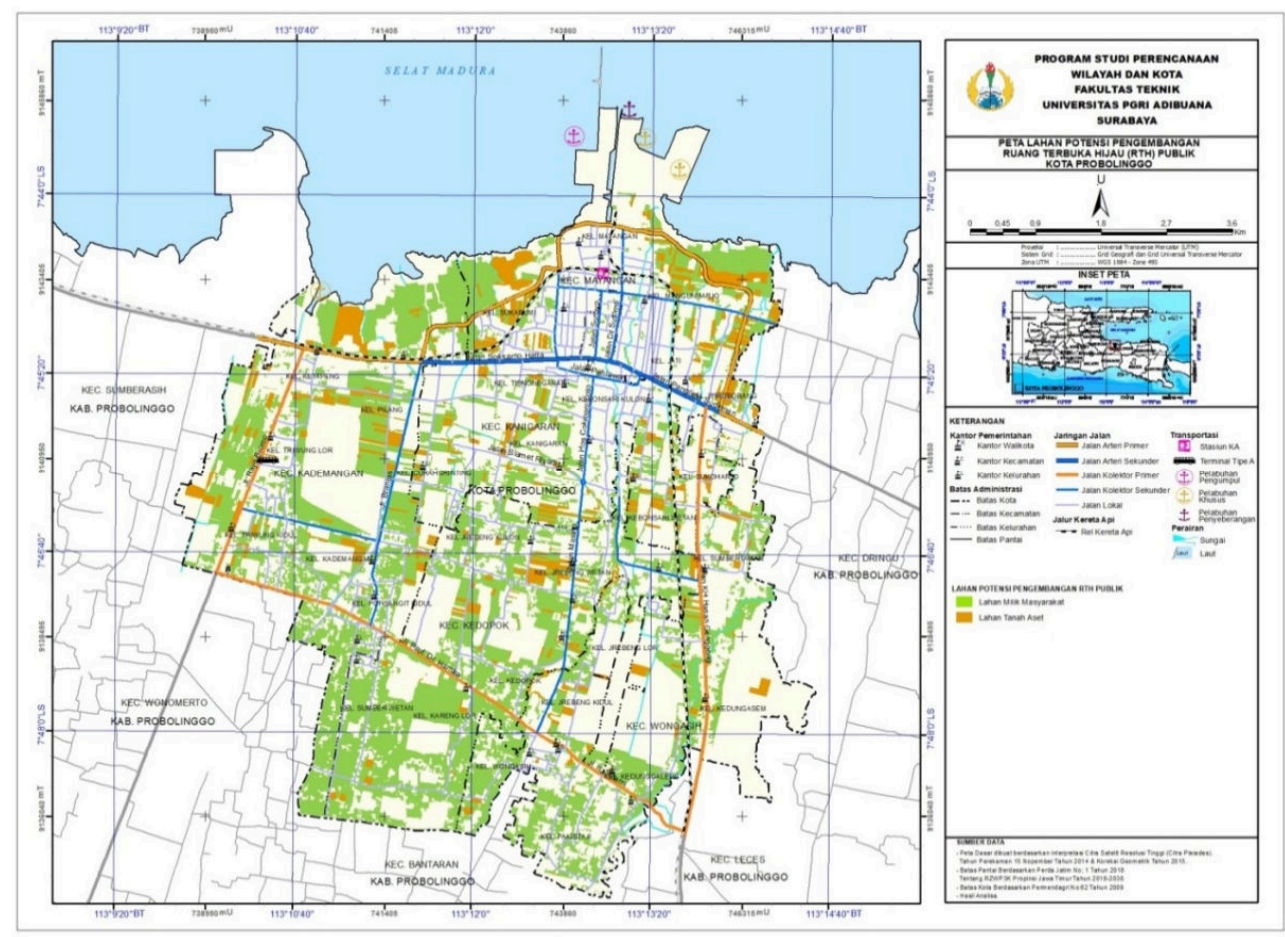

Gambar 3. Peta Lahan Potensi Pengembangan Ruang Terbuka Hijau (RTH) Publik Kota Probolinggo Tahun 2020 Berdasarkan Kepemilikan Lahan

Berdasarkan hasil analisis kebutuhan RTH Publik maka penambahan kebutuhan lahan RTH Publik di Kota Probolinggo diprioritaskan menggunakan tanah aset Pemerintah Kota Probolinggo dan kekurangannya menggunakan tanah milik masyarakat dengan rincian pada Tabel 5. Ketersediaan lahan mempengaruhi bentuk dan luasan ruang terbuka hijau yang akan dibangun (Caesarina \& Rahmani, 2019).

Tabel 5. Arahan Pemenuhan Kebutuhan Ruang Terbuka Hijau (RTH) Publik

\begin{tabular}{|r|l|r|r|r|}
\hline No & Kecamatan & $\begin{array}{c}\text { Penambahan RTH } \\
\text { Publik (Ha) }\end{array}$ & $\begin{array}{c}\text { Tanah } \\
\text { Aset (Ha) }\end{array}$ & $\begin{array}{c}\text { Tanah } \\
\text { Masyarakat (Ha) }\end{array}$ \\
\hline 1 & Kademangan & 198,57 & 61,98 & 136,59 \\
\hline 2 & Wonoasih & 172,34 & 28,26 & 144,08 \\
\hline 3 & Mayangan & 118,53 & 71,11 & 47,42 \\
\hline 4 & Kanigaran & 143,45 & 32,97 & 110,48 \\
\hline 5 & Kedopok & 207,64 & 29,48 & 178,16 \\
\hline \multicolumn{2}{|c|}{ Total } & $\mathbf{8 4 0 , 5 3}$ & $\mathbf{2 2 3 , 8 0}$ & $\mathbf{6 1 6 , 7 3}$ \\
\hline
\end{tabular}

Sumber : Hasil Analisa Tahun 2020

\section{KESIMPULAN DAN SARAN}

\subsection{Kesimpulan}

Berdasarkan hasil analisis pada penelitian ini yaitu Kebutuhan Ruang Terbuka Hijau (RTH) Publik di Kota Probolinggo dihitung menggunakan empat metode yaitu berdasarkan luas wilayah, jumlah penduduk, kebutuhan oksigen dan kebutuhan air. Hasil 
analisis menunjukkan bahwa berdasarkan luas wilayah membutuhkan penambahan seluas 840,53 ha. Arahan pemenuhan kebutuhan RTH Publik di Kota Probolinggo berdasarkan luas wilayah seluas 840,53 ha yang terdiri atas tanah aset pemerintah kota seluas 223,80 ha dan tanah milik masyarakat seluas 616,73 ha. Arahan pemenuhan kebutuhan RTH Publik berdasarkan jumlah penduduk seluas 210,12 ha yang terdiri dari tanah aset seluas 145,59 ha dan tanah masyarakat seluas 64,53 ha. Arahan Pemenuhan kebutuhan RTH Publik berdasarkan kebutuhan oksigen seluas 535,79 ha terdiri dari tanah aset seluas 223,80 ha dan tanah masyarakat seluas 311,99 ha. Arahan pemenuhan kebutuhan RTH Publik berdasarkan kebutuhan air tanah seluas 486,18 ha terdiri dari tanah aset seluas 208,25 ha dan tanah masyarakat seluas 277,93 ha. Pemenuhan kebutuhan RTH publik diprioritaskan menggunakan tanah aset Pemerintah Kota Probolinggo.

\subsection{Saran}

Saran yang dapat disampaikan dari hasil penelitian ini sebagai berikut:

1. Perlu adanya penyusunan Rencana Detail Tata Ruang (RDTR) dan Peraturan Zonasi Kota Probolinggo sebagai pedoman penetapan luasan dan lokasi ruang terbuka publik.

2. Perlu adanya penyeragaman peta dasar yang terorthoretrifikasi dalam melakukan pendataan RTH Publik di Kota Probolinggo.

3. Perlu adanya penelitian lanjutan mengenai lokasi ruang terbuka hijau publik dari aspek kepadatan penduduk, kelerengan dan aksesbilitas.

\section{DAFTAR PUSTAKA}

Caesarina, H. M., \& Rahmani, D. R. (2019). Penyediaan Ruang Terbuka Hijau dengan Pendekatan Kota Hijau di Perkotaan Martapura. Jurnal Planoearth Vol. 4 No. 1 (hlm. 11-17).

Islami, Y., \& Suheri, T. (2016). Arahan Pengembangan Ruang Terbuka Hijau Di Kota Banjarmasin. Jurnal Wilayah dan Kota Vol. 05 No. 01 (hlm. 18-26).

Karouw, C. J., Moniaga, I. L., \& Karongkong, H. H. (2019). Kajian Sebaran \& Ketersediaan Ruang Terbuka Hijau Di Perkotaan Tondano. Jurnal Spasial Vol. 6 No. 3 (hlm. 881-891).

Pemerintah Kota Probolinggo, 2006. Peraturan Daerah Kota Probolinggo Nomor 20 Tahun 2006 tentang Penataan dan Kelembagaan Kecamatan.

Pemerintah Republik Indonesia, 2007. Undang-Undang Republik Indonesia Nomor 26 Tahun 2007 tentang Penataan Ruang.

Kementerian Pekerjaan Umum, 2008. Peraturan Menteri Pekerjaan Umum No 05/PRT/M/2008 Tentang Pedoman Penyediaan dan Pemanfaatan Ruang Terbuka Hijau di Kawasan Perkotaan. Jakarta: Direktorat Jenderal Penataan Ruang Departamen Pekerjaan Umum.

Ningtyas, T. (2019). Pemanfaatan Ruang Terbuka Hijau (RTH) PublikDi Kota Kediri. Jurnal lmiah Manajemen Publik dan Kebijakan Sosia Vol. 3 No. 1 (hlm. 291-305). 
Jurnal Planologi Vol. 18 No. 2, Oktober 2021 Available : http://jurnal.unissula.ac.id/index.php/psa

Pemerintah Provinsi Jawa Timur, 2012. Peraturan Daerah Propinsi Jawa Timur Nomor 5 Tahun 2012 tentang Rencana Tata Ruang Wilayah Provinsi Tahun 2011-2031.

Priananta, I. (2010). Identifikasi Karakteristik Ruang Terbuka Hijau di Kota-Kota Pantai Indonesia (Studi Kasus: Kota Padang, Denpasar, dan Makassar)[Skripsi]. Departemen Arsitektur Lanskap Fakultas Pertanian Institut Pertanian Bogor.

Setiawan, A \& Hermana, J. (2013). Analisis Kecukupan Ruang Terbuka Hijau Berdasarkan Penyerapan Emisi CO2 dan Pemenuhan Kebutuhan Oksigen di Kota Probolinggo. Jurnal Teknik Pomits Vol. 2, No. 2 (hlm. 171-174).

Utami, M. R., \& S, R. (2019). Identifikasi Lokasi Potensial Untuk Pemenuhan Ruang Terbuka Hijau (RTH) Publik Aktif di Kota Salatiga. Jurnal Tata Loka Vol. 21 No. 3 (hlm. 459-472). 